\title{
The Anti-proliferation Effect of an Isolated Butanol Fraction of Tampa Badak (Voacanga foetida (Bl.) K. Schum) Leaves on Leukemia, Lung, and Cervical Cancer
}

\author{
Adriani Susanty ${ }^{1 *}$, Dachriyanus ${ }^{2}$, Yanwirasti ${ }^{3}$, Fatma Sri Wahyuni ${ }^{2}$, Andisyah Putri Sekar ${ }^{4,5}$, \\ Nur Alimin ${ }^{1}$, Magdazaleni ${ }^{1}$, Sri Esky Sofia ${ }^{1}$, Citra Kartika Dewi ${ }^{1}$ \\ ${ }^{1}$ Sekolah Tinggi Ilmu Farmasi Riau, Indonesia \\ ${ }^{2}$ Faculty of Pharmacy, University of Andalas, Indonesia \\ ${ }^{3}$ Faculty of Medicine, University of Andalas, Indonesia \\ ${ }^{4}$ Faculty of Pharmacy, Universitas Indonesia, Indonesia \\ ${ }^{5}$ Department of Cell and Chemical Biology, Leiden University Medical Center, The Netherlands
}

\begin{abstract}
Voacanga foetida (B1.) K.Schum leaves are known to have cytotoxic activity against blood cancer cells. This study was aimed to determine the potential of an isolated butanol fraction of Voacanga foetida (B1.) K.Schum leaves (Tb3 compound) in inhibiting the proliferation of several cancer cells, including leukemia (K562), lung cancer (A549), and cervical cancer (HeLa) using the dye exclusion method. We found that the percentage of anti-proliferation of the $\mathrm{Tb} 3$ compound was increased in a dose-dependent manner, where it showed 83\% (K562), 72.3\% (He-La), and 70.7\% (A549) inhibition at higher concentration. These values were relatively higher compared to doxorubicin as a positive control, $77.1 \%, 63.8 \%$, and $62.7 \%$, respectively. Moreover, the $\mathrm{IC}_{50}$ values of the $\mathrm{Tb} 3$ compound were still in the range of active cytotoxic compounds based on NCI classification, which is less than $4 \mu \mathrm{g} / \mathrm{mL} ; 0.5 \mu \mathrm{g} / \mathrm{mL}, 2.4 \mu \mathrm{g} / \mathrm{mL}$, and $3.6 \mu \mathrm{g} / \mathrm{mL}$ for $\mathrm{K} 562$, A549, and He-La, respectively. Therefore, this study indicated the potential anticancer effect of an isolated butanol fraction of the Tb3 compound to inhibit cancer cell proliferation, which provides an alternative for cancer therapy.
\end{abstract}

Keywords: Voacanga foetida; anti-proliferation; leukemia; lung cancer; cervical cancer

*corresponding author

Email: adrianisusanty@stifar-riau.ac.id

\section{INTRODUCTION}

In 2018 alone, GLOBOCAN has estimated 18.1 million new cancer cases and 9.6 million cancer deaths worldwide, which lung cancer was the most commonly diagnosed $(13 \%)$ and shared the highest percentage of death $(23.5 \%)$ (Siegel et al., 2019). The rate of new cases is then closely followed by leukemia (3.5\%) and cervical cancer $(0.8 \%)$, whereas the mortality cases were $0.7 \%$ and $3.8 \%$, respectively (Siegel et al., 2019). Similar to this, the percentage of mortality in Indonesia is also higher for lung cancer, leukemia, and cervical cancer than the new cases rate, which amounted to $12.6 \%$, $8.8 \%$, and $5.5 \%$, respectively. This trend is likely due to the poorer prognosis and limited access to timely diagnosis and treatment (IARC, 2018). However, this cancer prevalence can be reduced significantly through preventive measurement, early detection, and effective treatments (Riskesdas, 2013).

One breakthrough in cancer drug development is the use of natural compounds. Many natural compounds have been well investigated and effective as an anticancer treatment (Cui et al., 2018). Ideally, the anticancer drug should immediately kill cancer cells without endangering neighboring healthy cells. However, the standard cancer therapies, such as chemotherapy, radiotherapy, and surgery, can attack normal surrounding cells/tissues and induce several intolerable side effects. For instance, hair loss, nausea, vomiting, diarrhea, susceptibility to getting an infection, thrombocytopenia, neuropathy, and myalgia might lead to ineffective treatment for some cancer patients (Nurgali et al., 2018). Moreover, even cancer surgery could not remove the malignant cells entirely (Dipiro et al., 2011). Therefore, anticancer drugs derived from natural compounds, known as chemoprevention, could be used as an alternative treatment.

Voacanga foetida (B1) K. Schum (Apocynaceae), locally called 'Tampa badak,' is a plant species mainly distributed in Sumatra, Indonesia. The aqueous extract of $V$. foetida leaves or bark is commonly used to treat a wide range of skin conditions such as wounds, itches, swellings, and antimicrobial (Hadi et al., 2019). 
Another study revealed that $V$. foetida leaves also have anti-inflammatory, antipyretic, and analgesic activity (Susanty et al., 2014). A recent study found that $V$. foetida leaves are also potential as anticancer (Susanty et al., 2018) because the rich in alkaloids, such as voacangine, coronadine, voacristine, lombine (Hadi, 2019), and vobtusine (Arbain, 2012), which these substances have a potent effect of cytotoxic activity. Therefore, we aimed to evaluate the cytotoxic effect of $V$. foetida leaves on several cancer cell types, including lung cancer, leukemia, and cervical cancer.

\section{MATERIALS AND METHODS}

\section{Materials}

$V$. foetida leaves were collected from the Lembah Anai forest in Sumatera Barat. The Tb3 compound has resulted from an isolated butanol fraction of $V$. foetida leaves. K562, A549, and He-La cell line were obtained from the American Type Culture Collection (Rockville, MD) and were cultured in DMEM (GIBCO, Invitrogen Corp., New Zealand) with 10\% (v/v) FBS (Bio-west, Japan) $100 \mathrm{mg} / \mathrm{L}$ of streptomycin, and $100.000 \mathrm{U} / \mathrm{L}$ of penicillin at $37^{\circ} \mathrm{C}$ (Wako, Japan) and $5 \% \mathrm{CO}_{2}$.

\section{Methods}

\section{Isolation and extraction of Tb3 compound}

The extraction process was carried out by maceration using ethanol $96 \%$ solvent with three times replication for approximately five days through occasional stirring, and then filtered with cotton and transferred to the filtrate into a closed vessel. We used a rotary evaporator to obtain a thick ethanol extract of $V$. foetida leaves for a total weight of $65 \mathrm{~g}$. The thick ethanol extract for about $15 \mathrm{~g}$ was taken for further fractionation process, using a separating funnel with n-butanol as the solvent. The rotary evaporator was used again to get a concentrate. From this process, about $10 \mathrm{~g}$ of butanol fraction was obtained.

\section{Thin-layer chromatography (TLC) analysis}

The butanol fraction was poured into the TLC plate and put into a chamber containing a different gradient of hexane:ethyl as eluent. The SGP (Step Gradient Polarity) was used for the eluent gradients (Table 1). The column was then stored in vials and allowed to evaporate, whereas the stained TLC plate was seen under a UV lamp. The combination of eluents was monitored and resulting in three different fractions. The purification was then performed in this fraction, and recrystallization was carried out to remove impurities. After recrystallization, the $\mathrm{Tb} 3$ compound was obtained as much as $301 \mathrm{mg}$ (Figure 1).

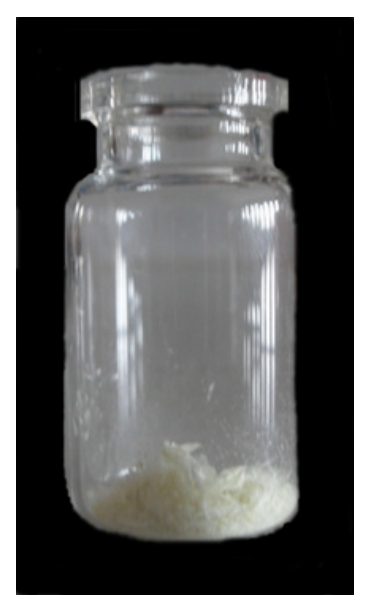

Figure 1. Tb3 Compound, shaped yellow-white needle-shaped crystal, weighing $301 \mathrm{mg}$.

\section{Identification of chemical functional group}

The characterization of the Tb3 compound was assessed using UV and IR spectrophotometry. This compound was also analyzed for the melting point using a Fisher John. The various eluent gradients on the TLC plate was tested for steroids by given a Lieberman Burchad color reagent, which the positive result was indicated with a blue color.

\section{Cell proliferation assay}

This assay was aseptically carried out in the laminar airflow cabinet (LAF-cabinet). Cancer cells (K562, A549, and He-La) containing $2 \times 10^{5}$ cells $/ \mathrm{mL}$ in DMEM medium placed in 24 well plates. The isolated Tb3 compound in the DMSO solvent at six different concentrations $(0 \mu \mathrm{g} /$ $\mathrm{mL}$ (negative control, only DMSO $10 \mu \mathrm{L}$ ); 0.5; 1; 2; 4; $8 \mu \mathrm{g} / \mathrm{mL}$ ) were exposed to the cancer cells. The cells were then incubated for 72 hours at $37^{\circ} \mathrm{C}$ and $5 \% \mathrm{CO}_{2}$. We did triplicate for each condition, and the assay was carried out three times. After the incubation, the medium was removed from the well, and $40 \mu \mathrm{L}$ trypsin-EDTA $0.2 \%$ was added (approximately 8 minutes incubation) to detach the remaining cells at the bottom of the well.

Table 1. TLC test results for Tb3 compound with different eluents gradients

\begin{tabular}{llll}
\hline No & Eluent & Eluent gradients & Rf Values \\
\hline 1 & n-hexane:ethyl acetate (A) & $7: 3$ & 0.25 \\
2 & n-hexane:ethyl acetate (B) & $6: 4$ & 0.50 \\
3 & n-hexane:ethyl acetate (C) & $5: 5$ & 0.62 \\
4 & ethyl acetate (D) & $100 \%$ & 0.67 \\
\hline
\end{tabular}


Subsequently, $960 \mu \mathrm{L}$ of fresh medium was added to the well, and the cell suspension was gently mixed with a micropipette until homogeneous. A total of $90 \mu \mathrm{L}$ of this cell suspension was moved to 96 wells plate, and $10 \mu \mathrm{L}$ of $1 \%$ trypan blue was added to the well. The plate was shaken until homogeneous, then $10 \mu \mathrm{L}$ of the mixture was dripped into an Improved Neubauer hemocytometer chamber gap to count the number of living cells in 25 boxes in the center of the counting chamber. Living cells were seen as transparent spheres with the cell nucleus in the middle of the areas, while dead cells were in irregularly formed blue patches. Cells were counted three times in five medium fields located in the middle of the massive plane. The five planes consist of four planes on edge, and one plane in the center (marked R), which the overall area is $80 \times 1 / 400 \mathrm{~mm}^{2}=0.2 \mathrm{~mm}^{2}$. The counting was started in a clockwise way. All cells in the upper and left boundary lines were considered for counting, whereas cells in the right and bottom boundaries were not included. The number of living cells per $\mathrm{mL}$, percent proliferation, and percent anti-proliferation were calculated by the modified formula (Doyle \& Griffith, 2000):

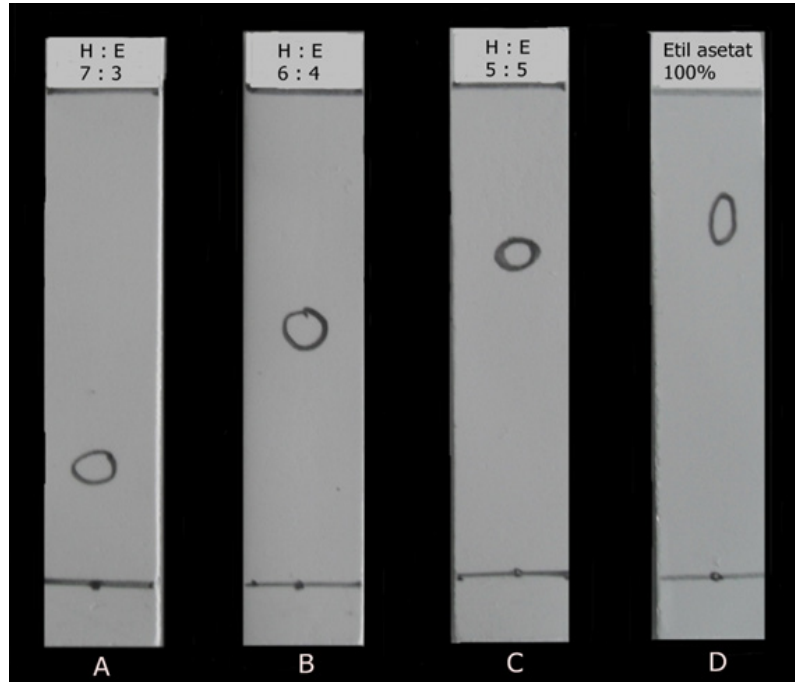

Figure 2. Thin Layer Chromatography (TLC) of Tb3 Compound (A, B, C, and D). (A) TLC with hexane eluent:ethyl acetate ratio of $7: 3$ with an $R f$ value of 0.25. (B) TLC with hexane eluent:ethyl acetate ratio of 6: 4 with an Rf value of 0.5 . (C) TLC with hexane eluent:ethyl acetate ratio of $5: 5$ with an $R f$ value of 0.62. and (D) TLC with $100 \%$ Ethyl acetate eluent with an $R f$ value of 0.67 .

$$
\begin{aligned}
& \sum \text { Cells }=\frac{\text { Number of cells in the counting cells }}{\text { The volume of the hemocytometer chamber }(\mathrm{mL})} \\
& \% \text { proliferation }=\frac{\text { Mean of living cells in treatment media }}{\text { Mean of living cells in negative control media (DMSO) }} \times 100 \% \\
& \% \text { Anti-proliferation }=100 \%-\% \text { Proliferation }
\end{aligned}
$$

The cancer cell inhibition was expressed by the $\mathrm{IC}_{50}$ value in which the concentration of isolated compounds in $\mu \mathrm{g} / \mathrm{mL}$ medium can inhibit $50 \%$ of cell proliferation in the incubation period of 72 hours. The $\mathrm{IC}_{50}$ value of the test solution was determined based on the equation of the relationship curve of the test solution concentration with the percentage of cancer cell death.

\section{Data analysis}

The percentage of anti-proliferation was plotted to the probit table to obtain the probit value. A curve was made between log concentration $(\mathrm{x})$ and probit $(\mathrm{y})$ to get a linear regression equation $\mathrm{y}=\mathrm{a}+\mathrm{bx}$, by entering an of $y=5$ in probit scale (probit of 50\%) and a value of $x$ (log concentration). The $\mathrm{IC}_{50}$ was determined by converting the concentration log value to the form of an antilog.

\section{RESULTS AND DISCUSSION}

The ethanol extract of $V$. foetida leaves $(10 \mathrm{~g})$ or called Tb3 compound was obtained from an isolated butanol fraction because this fraction is known to have rich alkaloids and steroids when check it using Thin-Layer Chromatography (TLC) analysis (Figure 2). The purification of this fraction was performed to remove the impurities, and the characterization was carried out using UV and Infrared spectrophotometry. Through the TCL analysis, we found that the gradient of hexane eluent:ethyl acetate ratio of 7:3 gives a better result of $\mathrm{Tb} 3$ compound's purity, which is characterized by the melting point of $128^{\circ}-130^{\circ} \mathrm{C}$ when identified by Fisher John. The result of UV spectrophotometry of Tb3 compounds in methanol solvents showed three consecutive wavelengths of $271.40 \mathrm{~nm}$ (0.491), 281.80 $\mathrm{nm}(0.522)$, and $293.40 \mathrm{~nm}(0.316)$, in which $281.80 \mathrm{~nm}$ was suggested as $\lambda$ max due to the n-electron * electron transition by a carbonyl chromophore $(\mathrm{C}=\mathrm{O})$ (Table 2 , Figure 3). Moreover, we identified several functional groups through IR spectrum, including -OH (3419.79 $\left.\mathrm{cm}^{-1}\right),=\mathrm{CH}$ aliphatic alkene group $\left(3024.38 \mathrm{~cm}^{-1}\right), \mathrm{CH}$ aliphatic group $\left(2868.15 \mathrm{~cm}^{-1}\right),=\mathrm{CH}$ aromatic alkene group $\left(1375.25 \mathrm{~cm}^{-1}\right)$, C-O $\left(1058.92 \mathrm{~cm}^{-1}\right)$, and $\mathrm{C}=\mathrm{O}$ 


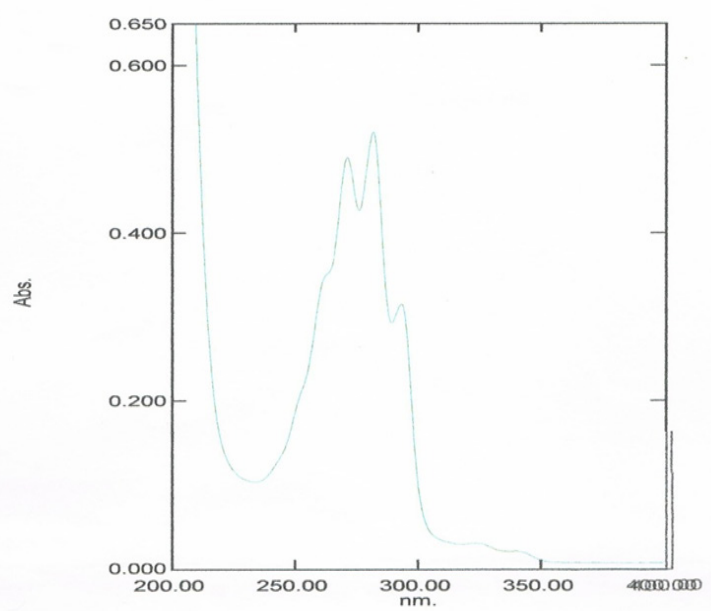

Figure 3. UV spectrophotometer of Tb3 compound at hexane eluent:ethyl acetate ratio of $7: 3$

(1600.92 $\mathrm{cm}^{-1}$ ) (Table 3, Figure 4). Most of the steroids have the property of containing oxygen functional groups as $\mathrm{C}=\mathrm{O}$. Therefore, to test if the $\mathrm{Tb} 3$ compound belongs to the steroids class, we performed qualitative testing by Lieberman Burchad color reagent on TLC plates, and the result gave a blue color, which indicated a positive result.

To further test the cytotoxic effect of the Tb3 compound in cancer, we used three types of cancer cells, such as blood cancer cells (K562), lung cancer cells (A549), and cervical cancer cells (He-La). We determined the percentage of anti-proliferation and the $\mathrm{IC}_{50}$, where we used doxorubicin as a positive control. The percentage of anti-proliferation was presented in Table 4. We found that the percentage of anti-proliferation of the $\mathrm{Tb} 3$ compound was increased in a dose-dependent manner, where it showed 83\% (K562), 72.3\% (He-La), and $70.7 \%$ (A549) inhibition at higher concentration (Figure 5). Meanwhile, the percentage of anti-proliferation of doxorubicin in K562, A549, and He-La are 77.1\%, $63.8 \%$, and $62.7 \%$, respectively (Figure 6). These values were relatively lower than the $\mathrm{Tb} 3$ compound, suggesting
Table 2. The wavelength and absorbance of $\mathbf{T b 3}$ compound at hexane eluent:ethyl acetate ratio of $7: 3$

\begin{tabular}{ll}
\hline Wavelength (nm) & Absorbance \\
\hline 271.40 & 0.491 \\
281.80 & 0.522 \\
293.40 & 0.316 \\
\hline
\end{tabular}

Table 3. Absorptions of functional groups of Tb3 compound using Infrared spectrum at hexane eluent:ethyl acetate ratio of $7: 3$

\begin{tabular}{ll}
\hline $\begin{array}{l}\text { Wavenumber } \\
\left(\mathbf{c m}^{-1}\right)\end{array}$ & Description \\
\hline $3419.79 \mathrm{~cm}^{-1}$ & OH stretch \\
$3024.38 \mathrm{~cm}^{-1}$ & $=\mathrm{CH}$ (aliphatic alkene group). \\
$2868.15 \mathrm{~cm}^{-1}$ & $\mathrm{CH}$ aliphatic strain group \\
$1600.92 \mathrm{~cm}^{-1}$ & stretch group C $=\mathrm{O}$ \\
$1375.25 \mathrm{~cm}^{-1}$ & $=\mathrm{CH}$ (aromatic alkene group) \\
$1058.92 \mathrm{~cm}^{-1}$ & C-O stretch \\
\hline
\end{tabular}

that the Tb3 compound has a similar effect in inhibiting cancer cell growth as strong as doxorubicin (Table 4). However, the $\mathrm{IC}_{50}$ of the $\mathrm{Tb} 3$ compound was relatively higher compared to doxorubicin, $0.5 \mu \mathrm{g} / \mathrm{mL}, 2.4 \mu \mathrm{g} / \mathrm{mL}$, and $3.6 \mu \mathrm{g} / \mathrm{mL}$ for K562, A549, and He-La, respectively. Whereas, the $\mathrm{IC}_{50}$ of doxorubicin in three consecutive cells are $0.14 \mu \mathrm{g} / \mathrm{mL}, 0.15 \mu \mathrm{g} / \mathrm{mL}$, and $0.18 \mu \mathrm{g} / \mathrm{mL}$. We used the $\mathrm{IC}_{50}$ value to determine the concentration that can kill $50 \%$ of cancer cells or induce cytotoxic activity.

It is notably known that doxorubicin is an anthracycline class of chemotherapy agents with a broad spectrum of anticancer activity and has been widely used in various cancer types. Besides being sensitive to lung cancer cells, doxorubicin is also responsive and potential to other diseases such as cervical cancer. This compound is specific to the $\mathrm{S}$ phase in the cell cycle by inducing template disturbances through the intercalation of DNA

Table 4. The percentage of the anti-proliferation effect of Tb3 compound and doxorubicin in K562, A549 and He-La cell lines

\begin{tabular}{lllllll}
\hline & \multicolumn{5}{c}{ Anti-proliferation (\%) } \\
\cline { 2 - 7 } Tb3 Compound & $0.5 \mu \mathrm{g} / \mathrm{mL}$ & $1 \mu \mathrm{g} / \mathrm{mL}$ & $2 \mu \mathrm{g} / \mathrm{mL}$ & $4 \mu \mathrm{g} / \mathrm{mL}$ & $8 \mu \mathrm{g} / \mathrm{mL}$ & $\mathbf{I C}_{\mathbf{5 0}} \mathbf{( \mu )}_{\mathbf{m L})}$ \\
\hline K562 & 52.1 & 54.3 & 68.1 & 77.7 & 83.0 & 0.5 \\
A549 & 20.7 & 34.5 & 50.0 & 60.4 & 70.7 & 2.4 \\
He-La & 3.4 & 17.0 & 34.0 & 52.5 & 72.9 & 3.6 \\
Doxorubicin & $0.04 \mu \mathrm{g} / \mathrm{mL}$ & $0.08 \mu \mathrm{g} / \mathrm{mL}$ & $0.16 \mu \mathrm{g} / \mathrm{mL}$ & $0.32 \mu \mathrm{g} / \mathrm{mL}$ & $0.64 \mu \mathrm{g} / \mathrm{mL}$ & 0.1 \\
\hline K562 & 18.9 & 34.4 & 59.8 & 67.2 & 77.1 & 0.2 \\
A549 & 34.5 & 44.5 & 51.7 & 56.9 & 63.8 & 0.2 \\
He-La & 35.6 & 39.0 & 49.2 & 57.6 & 62.7 & 0.2 \\
\hline
\end{tabular}




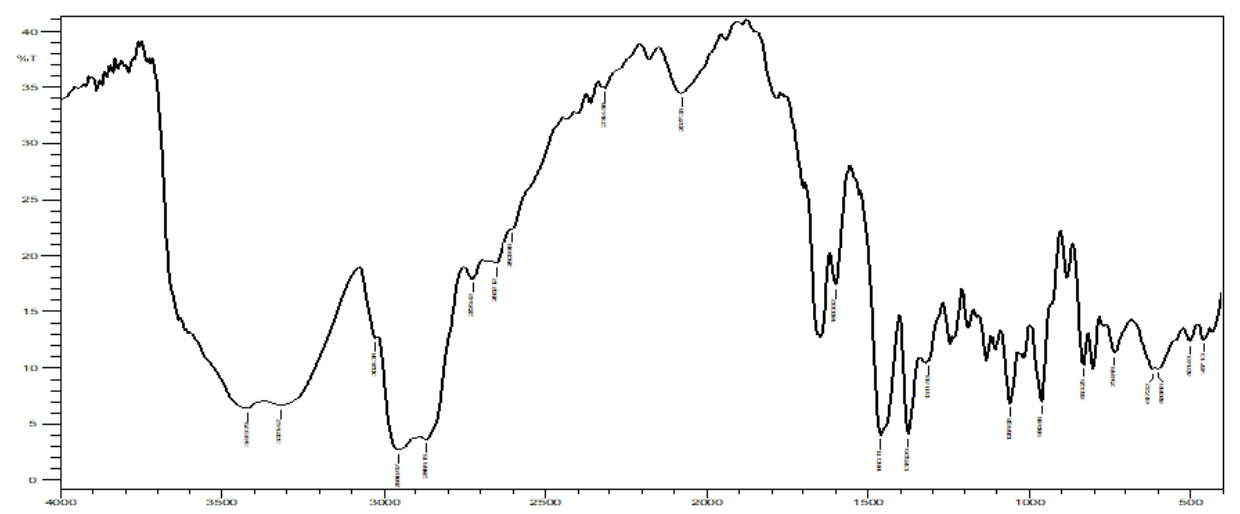

Figure 4. Infrared spectrophotometer of $\mathrm{Tb3}$ compound at 7: 3 ratio of n-hexane and ethyl acetate

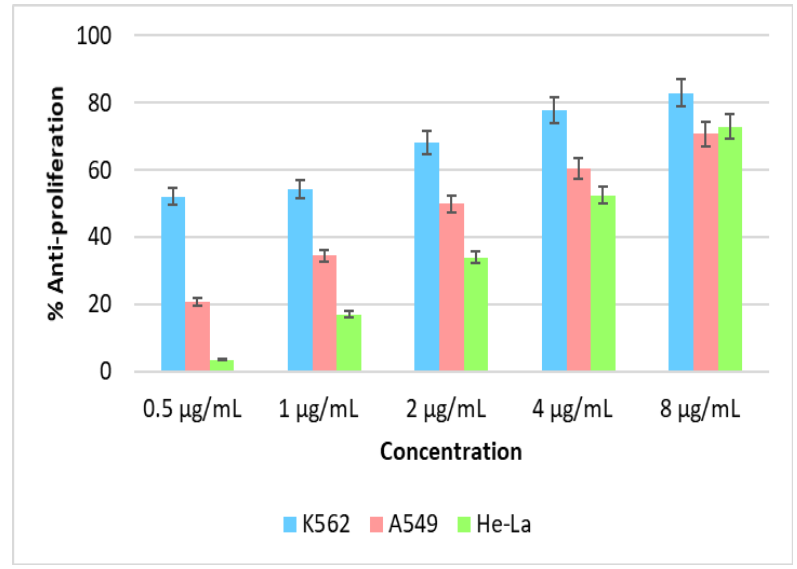

Figure 5. The percentage of the $\mathrm{Tb3}$ anti-proliferation effect in a dose-dependent manner. Values represent the mean of triplicate. Data represented as Mean \pm SEM.

base pairs, which leads to DNA strands breakage and impede DNA and RNA synthesis (Denard, Lee \& Ye, 2012) Another possible mechanism is by involving the binding of cell membrane lipids that will change various cellular functions and interact with DNA topoisomerase II to form DNA cutting complexes (Taymaz-Nikerel et al., 2018). Although the $\mathrm{IC}_{50}$ values of $\mathrm{Tb} 3$ compound in different cell types were higher than doxorubicin, the $\mathrm{Tb} 3$ compound is still adequate to induce cytotoxic activity because the values are still in the range of active cytotoxic compounds based on NCI classification because it is less than $4 \mu \mathrm{g} / \mathrm{mL}$ (Nurestri et al., 2009). Nevertheless, the plausible mechanism on how the Tb3 compound inhibit cancer cells needs to be fully elucidated.

According to Macabeo et al., 2009, the alkaloid compound of vocangine isolated from V.foetida has known to have potential anticancer activity. A recent study has reported that the $\mathrm{IC}_{50}$ of voacangine on HEPG2, A375, MDA-MB-231, SH-SY5Y, and CT26 cancer cells, were $10,14,8,7.6$, and $11 \mu \mathrm{g} / \mathrm{mL}$, respectively (Chen et al., 2016). These values were somewhat higher

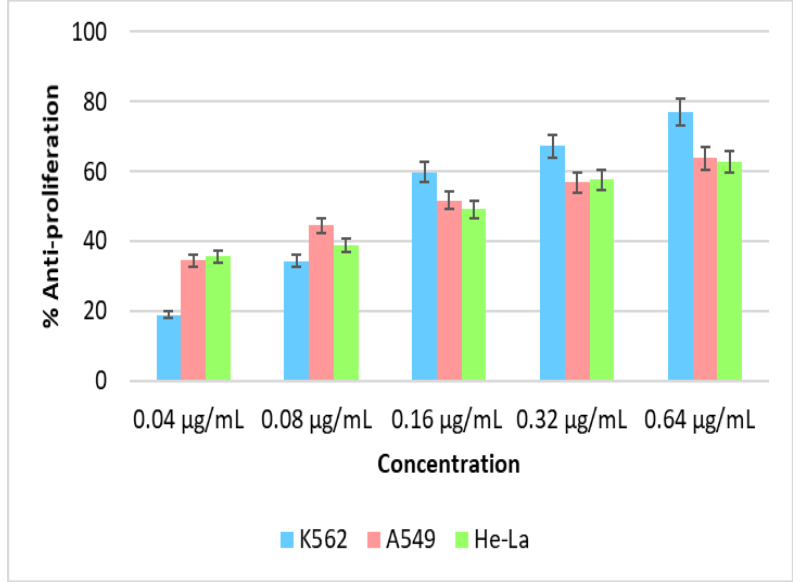

Figure 6. The percentage of doxorubicin antiproliferation effect in a dose-dependent manner as a positive control. Values represent the mean of triplicate. Data represented as Mean \pm SEM.

than the butanol fraction of $\mathrm{Tb} 3$ compound, which was rich in steroids. Therefore, this study showed that the butanol fraction of $\mathrm{Tb} 3$ compound has more cytotoxic activity than voacangine.

Besides, previously showed that voacangine could mediate cell apoptosis in THP-1 and HUVEC cells up to $80 \%$ when treated at a concentration with high concentration (Fiqueirado et al., 2010). Therefore, it suggested that the cytotoxic activity of the Tb3 compound probably could also mediate apoptosis. However, we do not include an apoptotic induction test due to the limitations of the Tb3 compound and the materials. The cytotoxic test is performed to confirm whether the Tb3 compound can be toxic or inhibit cancer cells growth. Apoptosis is a natural process of active cell death, in which cancer cells are brilliant in avoiding this process (Wong, 2011). Thus, this assay should be performed to determine how the mechanism of action of the Tb3 compound inhibits cancer cell growth.

The cancer treatment strategy is to return the apoptotic signaling pathway to its normal state so that it has the 
potential to reduce and eliminate cancer cells (Elmore, 2007). In contrast, necrosis is described as a passive cell death due to environmental disorders by releasing cellular contents, which causes uncontrolled inflammation (Fink $\&$ Cookson, 2005). Therefore, further studies need to be taken by adding an apoptotic activity assay using the flow cytometry with Annexin V-PI method to explain the cytotoxic activity of the Tb3 compound, more specifically whether by inducing apoptosis or necrosis. Annexin $\mathrm{V}$ is a recombinant phosphatidylserine-binding protein that interacts strongly and specifically with phosphatidylserine residues and can be used to detect apoptosis (Niu \& Chen, 2010).

\section{CONCLUSION}

The butanol fraction of the Tb3 compound has potential anticancer effect in several types of cancers, including leukemia, lung cancer, and cervical cancer.

\section{ACKNOWLEDGMENTS}

Thanks to the Directorate of Research and Community Service, Directorate of Research Strengthening and Development of The Ministry of Research, Technology, and Higher Education, According to the research contract of 2018, NO: 049/K10/KM/KONTRAKPENELITIAN/2018 and to the Director of Sekolah Tinggi Ilmu Farmasi Riau for the support my doctoral study. Thank you to the Faculty of Medicine, Andalas University, and Central Laboratory of Isotopes and Radiation Technology Application (PATIR)-BATAN.

\section{REFERENCES}

Arbain, D. (2012). Inventory, constituents, and conservation of biologically important Sumatran plants. In Natural Product Communications. https://doi. org/10.1177/1934578x1200700627

Chen, H. M., Yang, Y. T., Li, H. X., Cao, Z. X., Dan, X. M., Mei, L., Guo, D. Le, Song, C. X., Dai, Y., Hu, J., \& Deng, Y. (2016). Cytotoxic monoterpenoid indole alkaloids isolated from the barks of Voacanga Africana Staph. Natural Product Research. https://doi.org/10.108 0/14786419.2015.1046132

Cui, Q., Yang, D. H., \& Chen, Z. S. (2018). Special issue: Natural products: Anticancer and beyond. Molecules, 23(6), 11-14. https://doi.org/10.3390/ molecules23061246

Denard, B., Lee, C., \& Ye, J. (2012). Doxorubicin blocks the proliferation of cancer cells through proteolytic activation of CREB3L1. ELife, 2012(1), 1-14. https:// doi.org/10.7554/eLife.00090
Dipiro, T.J., Talbert, L.R., Yee, C.G., Matzke, R.G., Wells, G.B., and Posey, M.L, (2011). Cancer Treatment And Chemotherapy, Pharmacotherapy A Pathophysiologic Approach 8th Edition.

Doyle, A., dan Griffiths (2000). J, Cell and Tissue Culture for Medical Research, John Willey and Sons Ltd, New York

Elmore, S. (2007). Apoptosis: A Review of Programmed Cell Death. Toxicologic Pathology, 35(4), 495-516. https://doi.org/10.1080/01926230701320337

Fink, S. L., \& Cookson, B. T. (2005). Apoptosis, pyroptosis, and necrosis: Mechanistic description of dead and dying eukaryotic cells. Infection and Immunity, 73(4), 1907-1916. https://doi.org/10.1128/ IAI.73.4.1907-1916.2005

Figueiredo, E. R., Vieira, I. J. C., De Souza, J. J., BrazFilho, R., Mathias, L., Kanashiro, M. M., \& Côrtes, F. H. (2010). Isolamento, identificação e avaliação da atividade antileucêmica de alcaloides indólicos monoterpênicos de Tabernaemontana salzmannii A. DC., Apocynaceae. Brazilian Journal of Pharmacognosy. https://doi. org/10.1590/S0102-695X2010000100016

Hadi, S., Desy Ratnasari, B., Septiyana, M., Priyambodo, S., \& Sudarma, I. M. (2019). Antibacterial Assay and Alkaloid Lombine Distribution Study of Voacanga foetida (BI) Rolfe from Lombok Island. Oriental Journal of Chemistry. https://doi.org/10.13005/ojc/350133

Lee, C. C., \& Houghton, P. (2005). Anti-proliferation of plants from Malaysia and Thailand used traditionally to treat cancer. Journal of Ethnopharmacology. https://doi. org/10.1016/j.jep.2005.01.064

Macabeo, A. P., Alejandro, G. J., Hallare, A., Vidar, W., \& Villaflores, O. (2009). Phytochemical survey and pharmacological activities of the indole alkaloids in the genus voacanga thouars (apocynaceae) - An update. In Pharmacognosy Reviews.

Niu, G., \& Chen, X. (2010). Apoptosis Imaging : Beyond Annexin V. Focus Moleculae Imaging, 51(11), 59-1663. https://doi.org/10.2967/jnumed.110.078584

Nurestri, S., Malek, A., Shin, S. K., Wahab, N. A., \& Yaacob, H. (2009). Cytotoxic Components of Pereskia bleo (Kunth) DC. (Cactaceae) Leaves. HCT 116, 17131724. https://doi.org/10.3390/molecules 14051713

Nurgali, K., Jagoe, R. T., \& Abalo, R. (2018). Editorial: Adverse effects of cancer chemotherapy: Anything new to improve tolerance and reduce sequelae? Frontiers in 
Pharmacology, 9(MAR), 1-3. https://doi.org/10.3389/ fphar.2018.00245

Riskesdas. (2013). Riset Kesehatan Dasar 2018. Kementrian Kesehatan Republik Indonesia. https://doi. org/1 Desember 2013

Siegel, R. L., Miller, K. D., \& Jemal, A. (2019). Cancer statistics, 2019. CA: A Cancer Journal for Clinicians. https://doi.org/10.3322/caac.21551

Susanty, A., Dachriyanus, D., Yanwirasti, Y., Wahyuni, F. S., Fadhli, H., \& Aswan, P. A. (2018). Aktivitas Sitotoksik Ekstrak Etil Asetat Daun Tampa Badak (Voacanga foetida (B1.)K.Schum) pada Kanker Kolon HTB-38. JSFK (Jurnal Sains Farmasi \& Klinis). https:// doi.org/10.25077/JSFK.5.2.142-146.2018
Susanty, A., Fernando, A., \& Adelin, I. (2014). Efek Analgetik Ekstrak Etanol Daun Tumbuhan Voacanga foetida (B1.) K. Schum) pada Tikus Putih Jantan. Jurnal Sains Farmasi \& Klinis. https://doi.org/10.25077/ jsfk.1.1.1-9.2014

Taymaz-Nikerel, H., Karabekmez, M. E., Eraslan, S., \& Kurdar, B. (2018). Doxorubicin induces an extensive transcriptional and metabolic rewiring in yeast cells. Scientific Reports, 8(1), 1-14. https://doi.org/10.1038/ s41598-018-31939-9

Wong, R. S. Y. (2011). Apoptosis in cancer: From pathogenesis to treatment. Journal of Experimental and Clinical Cancer Research, 30(1), 1-14. https://doi. org/10.1186/1756-9966-30-87 